\title{
PERANCANGAN APLIKASI PENGELOLAAN KEPEGAWAIAN BERBASIS WEB DI PT. TRADERS FAMILY INTERNATIONAL
}

\section{Design Of Employee Management Application Web Based At Pt. Traders Family International}

\author{
Ignatius Adrian Mastan ${ }^{1)}$, Metta Mellisa Tyo ${ }^{2)^{*}}$ \\ 1), 2) Program Studi Sistem Informasi, Universitas Bunda Mulia, Jakarta
}

Diterima 13 Agustus 2020 / Disetujui 24 Agustus 2020

\begin{abstract}
PT. Traders Family International is a trader-based forex consulting services company that focuses its business on changing the face of the forex industry in Indonesia towards a more modern, safe, transparent and reliable direction. In this company, applications for permits and leave are still using the manual method, by filling out a permit and leave application form which can damage or lose forms so that it can become a problem in calculating employee salaries.

Employees of PT. Traders Family International uses paper-based applications for permits and leave and still uses Microsoft Excel which has not been properly integrated between the process of attendance and permit and leave applications. As a result, HRD takes longer in making attendance reports and can result in errors in making attendance reports.

The result of this research is a web-based employee management application created using the PHP programming language and MySQL database, this application can be accessed easily by company employees in areas that are reached by the company's local area network. With this application employees can also find out the remaining leave, so that employees can apply for leave without asking the HRD to find out the remaining leave.
\end{abstract}

Keywords: Employee Management, Human Resources, Web, Applications

\section{ABSTRAK}

PT. Traders Family International adalah sebuah perusahaan jasa konsultan forex berbasis trader yang memusatkan bisnisnya pada perubahan wajah industri forex di Indonesia ke arah yang lebih modern, aman, transparan dan terpercaya. Pada perusahaan ini pengajuan izin dan cuti masih menggunakan cara manual, yaitu dengan mengisi formulir pengajuan izin dan cuti yang dapat mengalami kerusakan kertas formulir ataupun kehilangan formulir sehingga dapat menjadi masalah dalam perhitungan gaji pegawai.

Pegawai PT. Traders Family International menggunakan paper-based untuk pengajuan permohonan izin mapupun cuti dan masih menggunakan Microsoft Excel yang belum terintegrasi dengan baik antara proses absensi dan pengajuan izin maupun cuti. Akibatnya, HRD memerlukan waktu yang lebih lama dalam membuat laporan absensi dan dapat mengakibatkan kesalahan dalam membuat laporan absensi.

Hasil dari penelitian ini adalah aplikasi pengelolaan karyawan berbasis web yang dibuat menggunakan bahasa pemrograman $P H P$ dan basis data $M y S Q L$, aplikasi ini dapat diakses dengan mudah oleh pegawai perusahaan di area yang terjangkau dengan local area network perusahaan. Dengan aplikasi ini pegawai juga dapat mengetahui sisa cuti, sehingga pegawai dapat mengajukan cuti tanpa bertanya ke bagian HRD untuk mengetahui sisa cuti.

Kata Kunci : Pengelolaan Pegawai, Human Resource, Web, Aplikasi

*Korespondensi Penulis :

E-mail: metta07tyo@gmail.com 


\section{PENDAHULUAN}

Penggunaan sistem informasi pada zaman ini sangat berkembang pesat dan cepat, sistem informasi berperan penting dalam mendukung manajemen dalam menjalankan setiap lini kegiatan operasional perusahaan (Pratama, 2017:22). Sumber daya manusia merupakan sumber fisik, sedangkan sistem dan teknologi informasi merupakan sumber teknis. Sistem konseptual yang digunakan untuk mengelola sumber daya manusia di perusahaan disebut juga sistem informasi sumber daya manusia atau Human Resource Information System (HRIS). Tanpa ada peran dari sistem informasi sumber daya manusia, perusahaan akan merasa kesulitan dalam mengelola sumber daya manusia (Hussein, 2014:2).

Salah satu perusahaan yang membutuhkan aplikasi pengelolaan kepegawaian adalah PT. Traders Family International. Selama beroperasi pengelolaan kepegawaian masih menggunakan paperbased untuk pengajuan permohonan izin mapupun cuti dan masih menggunakan Microsoft Excel yang belum terintegrasi dengan baik antara proses absensi dan pengajuan izin maupun cuti. Akibatnya, HRD memerlukan waktu yang lebih lama dalam membuat laporan absensi dan dapat mengakibatkan kesalahan dalam membuat laporan absensi. Hal tersebut akan mempengaruhi pada perhitungan gaji pegawai, karena salah satu ketentuan memotong gaji pegawai dihitung berdasarkan jam keterlambatan, sehingga dapat mengakibatkan kesalahan pembayaran gaji serta kesalahan dalam membuat laporan gaji pegawai. Selain itu, data tersebut hanya dapat dilihat oleh pihak HRD dan manajer, sehingga pegawai yang bersangkutan tidak dapat melihat data absensi dan sisa cuti pegawai. Pegawai tidak dapat melakukan pengecekan kesalahan yang dilakukan oleh HRD misalnya dalam perhitungan sisa cuti pegawai. Dalam hal ini pihak HRD membutuhkan suatu sistem informasi yang lebih baik untuk menanggulangi masalahmasalah tersebut. Pihak HRD harus memiliki database yang dapat menyimpan semua data perusahaan dengan baik. Database tersebut akan mencakup semua data perusahaan yang bertujuan untuk melakukan kontrol terkait aktivitas absensi, izin, dan cuti serta menghindari terjadinya kerusakan dan kehilangan data. Aplikasi pengelolaan kepegawaian yang akan diterapkan di PT. Traders Family International adalah menggunakan Human Resource Information System (HRIS) berbasis web, dikarenakan lebih mudah untuk diakses dimana saja oleh pegawai selama berada pada lingkungan yang terjangkau oleh local area network PT. Traders Family International.

Berdasarkan permasalahan di atas, maka peneliti merancang Aplikasi Pengelolaan Kepegawaian dengan tujuan dapat membantu mengatasi masalah yang dihadapi oleh pihak HRD dan pegawai dalam memantau aktivitas absensi, pengajuan izin dan pengajuan cuti pegawai di PT.Traders Family International.

\section{TINJAUAN PUSTAKA}

\section{A. Sumber Daya Manusia}

Sumber Daya Manusia (SDM) merupakan elemen utama organisasi dibandingkan dengan elemen lain seperti modal, teknologi, dan uang, sebab manusia itu sendiri yang mengendalikan yang lain (Ismail, 2010:111). Manusia memilih teknologi, manusia yang mencari modal, manusia yang menggunakan dan memeliharanya, dan manusia dapat menjadi salah satu sumber keunggulan bersaing dan 
sumber keunggulan bersaing yang langgeng. Oleh karena itu, pengelolaan sumber daya manusia dalam organisasi menjadi suatu hal yang sangat penting.

Program yang berkaitan dengan usaha mendapatkan sumber daya manusia dilakukan dengan berbagai kegiatan spesifik seperti analisis jabatan, perencanaan sumber daya manusia, perekrutan, penyeleksian, dan penempatan. Setelah sumber daya manusia diperoleh, perlu dilakukan pengembangan termasuk pengembangan sikap dan skill serta kemampuan yang dilakukan melalui pelatihan-pelatihan, membantu pegawai mencapai tujuan kariernya dengan pengelolaan karier, dan melakukan penilaian dalam rangka mencari kekurangan untuk segera diperbaiki. Setelah mereka dilatih dan kemudian bekerja dengan baik, kebutuhankebutuhan dasar sebagai manusia harus dipenuhi untuk memelihara dan meningkatkan loyalitas sumber daya manusia terhadap organisasi yang berguna untuk meningkatkan kinerja.

\section{B. Web}

WWW atau World Wide Web atau web saja merupakan sebuah sistem yang saling terkait dalam sebuah dokumen yang berformat hypertext yang berisi beragam informasi, baik tulisan, gambar, suara, video, dan informasi multimedia lainnya dan dapat diakses melalui sebuah perangkat yang disebut web browser. Untuk menterjemahkan dokumen dalam bentuk hypertext ke dalam bentuk dokumen yang bias dipahami, maka web browser melalui web client akan membaca halaman web yang tersimpan di sebuah web server melalui protokol yang biasa disebut http atau Hypertext Transfer Protocol (Erinawati, 2012:42).

\section{Waterfall Model}

Waterfall Model SDLC (System Developement Life Cycle) adalah sebuah proses pengembangan perangkat lunak sekuensial dimana kemajuan dalam pengembangan dianggap seperti mengalir ke bawah (mirip dengan air terjun) melewati daftar fase yang harus dijalankan untuk berhasil membangun perangkat lunak komputer (Bassil, 2012:2).

Awalnya, itu Waterfall Model diusulkan oleh Winston W. Royce di tahun 1970 untuk menggambarkan atau menjelaskan aktivitas rekayasa perangkat lunak apa saja yang mungkin dilakukan. Waterfall Model mendefinisikan beberapa fase berturut-turut yang harus diselesaikan satu demi satu dan hanya akan berpindah ke fase berikutnya ketika fase sebelumnya selesai sepenuhnya. Untuk alasan ini, Waterfall Model berisifat rekursif dimana dalam setiap fase dapat berulang tanpa henti sampai hasil yang memuaskan.

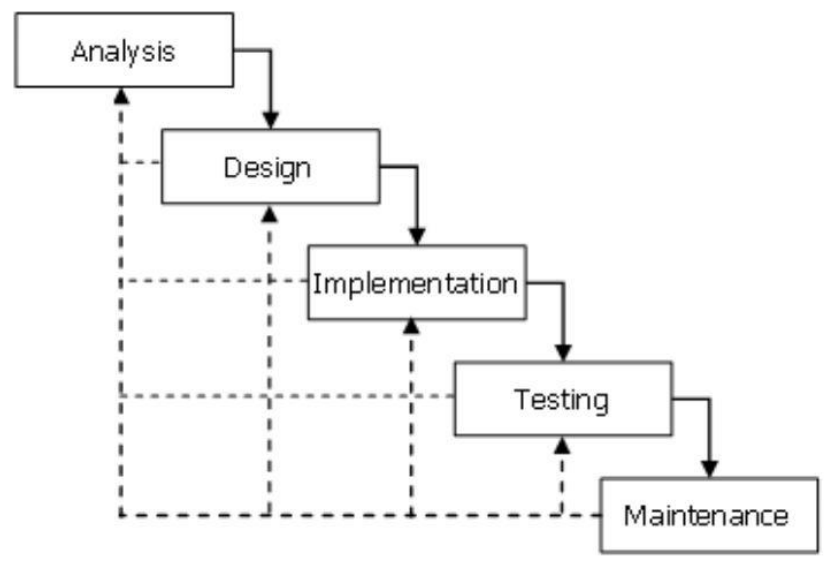

\section{Gambar 1. Waterfall Model}

(Bassil, 2012:2)

Menurut referensi Bassil (2012:2), Waterfall Model terdiri dari lima fase, yaitu :

1. Analysis

Sering dikenal juga sebagai SRS (Software Requirements Specification) adalah deskripsi lengkap dan komprehensif tentang perilaku perangkat lunak yang akan dikembangkan. Ini melibatkan analis sistem dan bisnis untuk 
mendefinisikan persyaratan, baik fungsional maupun non-fungsional. Biasanya, kebutuhan fungsional didefinisikan dengan menggunakan kasuskasus penggunaan yang menggambarkan interaksi pengguna dengan perangkat lunak. Hal-hal tersebut termasuk persyaratan seperti tujuan, ruang lingkup, perspektif, fungsi, atribut perangkat lunak, karakteristik pengguna, spesifikasi fungsionalitas, kebutuhan antarmuka atau tampilan, dan kebutuhan basis data. Sebaliknya, kebutuhan non-fungsional mengacu pada berbagai kriteria, batasan, dan kebutuhan yang menentukan desain dan operasi pada perangkat lunak daripada perilaku tertentu. Hal ini termasuk beberapa properti, seperti: keandalan, dapat diuji coba, ketersediaan, pemeliharaan, kinerja, dan standar kualitas.

2. Design

Fase ini adalah proses perencanaan dan pemecahan masalah untuk solusi perangkat lunak. Hal ini melibatkan pengembang dan desainer perangkat lunak untuk menentukan rencana dalam membuat sebuah solusi yang meliputi desain algoritma, desain arsitektur perangkat lunak, skema konseptual database dan desain diagram logis, desain konsep, desain antarmuka pengguna grafis, dan definisi struktur data.

\section{Implementation}

Fase ini mengacu pada realisasi terhadap kebutuhan bisnis dan spesifikasi desain menjadi suatu program yang dapat dieksekusi secara konkret, database, situs $w e b$, atau komponen perangkat lunak melalui pemrograman dan penyebaran. Fase ini merupakan tempat dimana kode asli ditulis dan dikompilasi menjadi suatu aplikasi operasional, dan dimana file database dan teks dibuat. Dengan kata lain, fase ini adalah proses mengubah seluruh kebutuhan dan cetak biru (blueprint) menjadi lingkungan produksi.

4. Testing

Fase ini juga dikenal sebagai proses verifikasi dan validasi yang merupakan proses untuk memeriksa bahwa solusi perangkat lunak memenuhi persyaratan dan spesifikasi dan dapat memenuhi tujuan yang dimaksudkan. Verifikasi adalah proses mengevaluasi perangkat lunak untuk menentukan apakah produk dari fase pengembangan yang diberikan memenuhi kondisi yang dikenakan pada awal fase itu. Validasi adalah proses evaluasi perangkat lunak selama atau pada akhir proses pengembangan untuk menentukan apakah memenuhi persyaratan yang ditentukan. Selain itu, fase pengujian (testing) adalah suatu cara untuk melakukan debugging dimana bug dan gangguan sistem dapat ditemukan, diperbaiki, dan disempurnakan.

\section{Maintenance}

Fase ini adalah proses memodifikasi solusi perangkat lunak setelah pengiriman dan penerapan untuk memperbaiki hasil, memperbaiki kesalahan, dan meningkatkan kinerja dan kualitas. Kegiatan pemeliharaan tambahan dapat dilakukan dalam fase ini termasuk mengadaptasi perangkat lunak ke lingkungannya, mengakomodasi kebutuhan pengguna baru, dan meningkatkan keandalan perangkat lunak.

\section{KERANGKA PENELITIAN}

Kerangka Penelitian ini dimulai dari Tahap Pengembangan Sistem menggunakan Metode Waterfall, Pemodelan Data menggunakan Entity Relationship Diagram (ERD), desain berorientasi object menggunakan use case diagram, activity diagram, class diagram. Bahasa pemrograman yang digunakan adalah : PHP, 
Versi Online: http://journal.ubm.ac.id/index.php/jbase DOI: http://dx.doi.org/10.30813/jbase.v3i2.2271
HTML, CSS, Javascript. Dapat dilihat lebih detail pada Gambar 2.

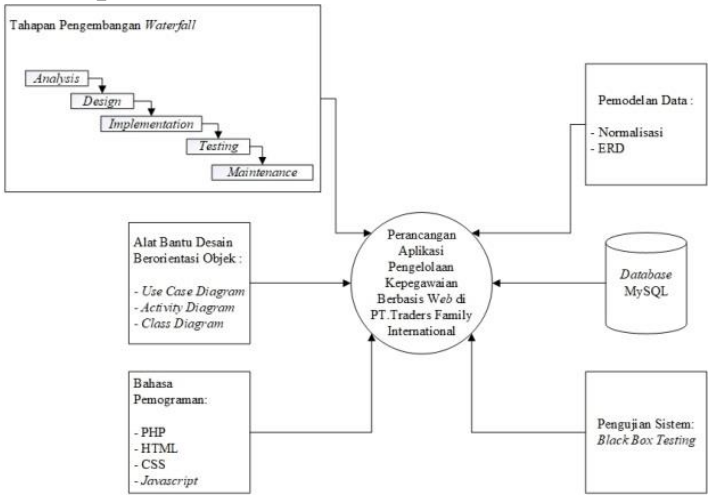

Gambar 2. Kerangka Penelitian

\section{HASIL DAN PEMBAHASAN}

\section{A. Use Case Diagram}

Use Case Diagram pada Gambar 3 menggambarkan hal-hal sebagai berikut ini :

1. Pegawai, Jabatan Manajer, dan HRD berperan sebagai aktor.

2. Semua pegawai dapat mengakses dan mengelola data identitas diri, pengajuan izin, pengajuan cuti dan dapat memantau absensi diri.

3. Pegawai dengan jabatan manajer dapat mengakses dan mengelola persetujuan pengajuan izin dan cuti pegawai.

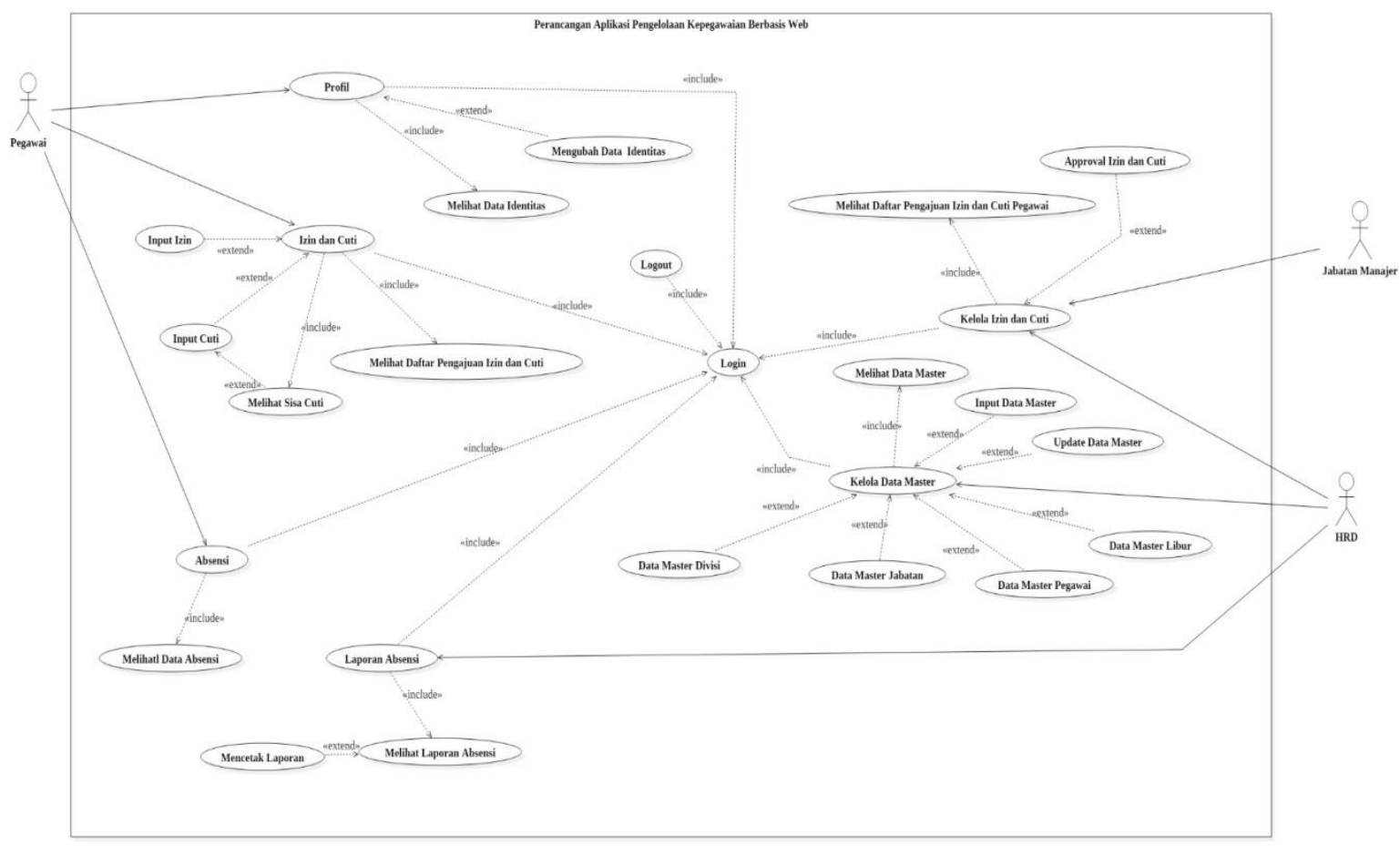

Gambar 3. Use Case Diagram 
Use Case Diagram pada Gambar 3 menggambarkan hal-hal sebagai berikut ini :

1. Pegawai, Jabatan Manajer, dan HRD berperan sebagai aktor.

2. Semua pegawai dapat mengakses dan mengelola data identitas diri, pengajuan izin, pengajuan cuti dan dapat memantau absensi diri.

3. Pegawai dengan jabatan manajer dapat mengakses dan mengelola persetujuan pengajuan izin dan cuti pegawai.
4. HRD dapat mengakses dan mengelola persetujuan pengajuan izin dan cuti pegawai, memantau absensi pegawai, mengelola data pegawai, dan pembuatan laporan untuk membantu dalam perhitungan gaji pegawai.

\section{B. Entity Relationship Diagram}

Perancangan ERD bertujuan untuk memberikan gambaran mengenai database yang akan digunakan untuk menyimpan data-data yang diperlukan dalam aplikasi pengelolaan kepegawaian, seperti yang ditunjukkan pada Gambar 4

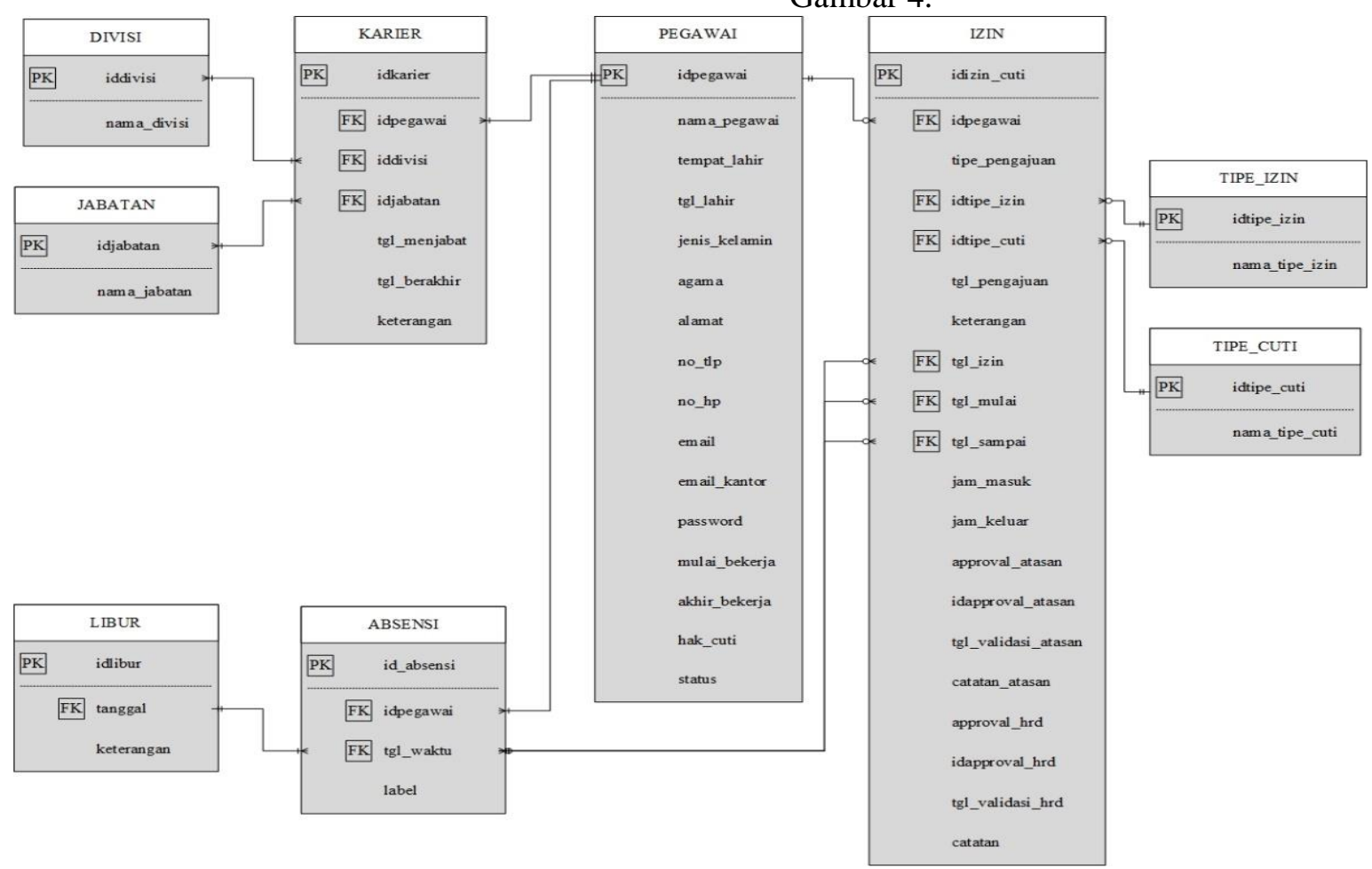

Gambar 4. Entity Relationship Diagram

\section{Desain Input Output}

Tampilan dari halaman login dapat dilihat pada Gambar 5, dimana setiap pengguna yang ingin masuk ke dalam aplikasi harus memiliki akses berupa email dan password yang terdaftar. Jika pengguna aplikasi lupa dengan password, maka pengguna bisa meminta HRD untuk mengubah password sehingga pengguna bisa login kembali.

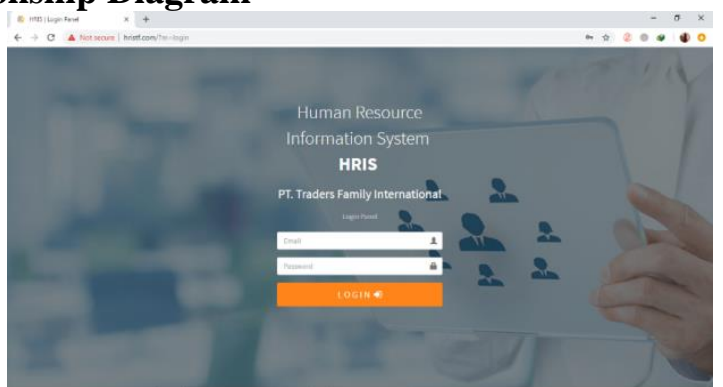

Gambar 5. Halaman Login

Halaman dasbor aplikasi adalah tampilan dari halaman utama aplikasi yang menampilkan 
Versi Online: http://journal.ubm.ac.id/index.php/jbase DOI: http://dx.doi.org/10.30813/jbase.v3i2.2271 Hasil Penelitian beberapa informasi mengenai data pengguna, dapat dilihat pada Gambar 6, dibawah ini

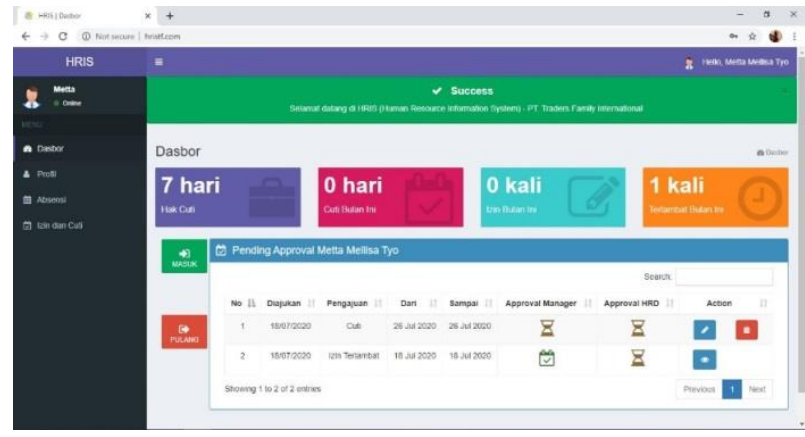

Gambar 6. Halaman Dasbor Aplikasi

Gambar 7 menampilkan halaman menu Izin dan Cuti yang berisikan daftar pengajuan izin dan cuti yang dilakukan pengguna aplikasi. Pengajuan izin dan cuti dapat ditambah dengan menekan tombol hijau Buat Baru. Pengajuan izin dan cuti yang ada pada daftar tersebut dapat diubah dan dihapus tergantung kebutuhan.

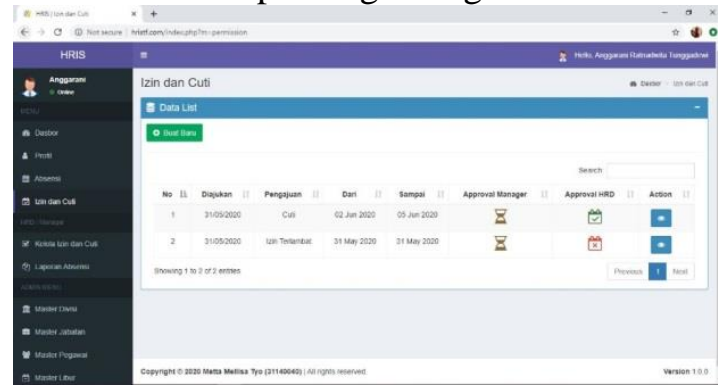

\section{Gambar 7. Tampilan Menu Izin dan Cuti}

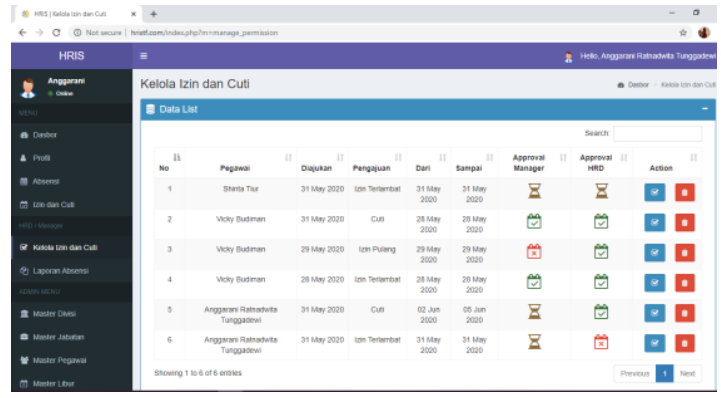

Gambar 8. Tampilan Kelola Izin dan Cuti

Gambar 8 menampilkan halaman menu Kelola Izin dan Cuti yang hanya dimiliki oleh pegawai dengan jabatan manajer dan HRD yang berisikan daftar pengajuan izin dan cuti yang dilakukan oleh pegawai yang membutuhkan approval dari atasannya dan HRD. Untuk melakukan approval, manajer atau HRD bisa memilih aksi yang ada pada samping daftar yaitu dibagian action dengan pilihan approval dan delete yang digunakan untuk menghapus data pengajuan izin dan cuti.

Gambar 9 menampilkan halaman menu Laporan Presensi yang hanya dimiliki oleh HRD yang berisikan daftar presensi pegawai yang bekerja di perusahaan yang meliputi total hari masuk kerja, total hari terlambat, total hari izin, total hari sakit, total hari cuti, total hari alpha, dan total hari kerja berdasarkan tanggal yang ditentukan oleh HRD sebagai pengguna aplikasi. Laporan ini dapat di download melalui tombol Export dan dicetak melalui tombol Print dan laporan ini akan diserahkan ke bagian finance untuk perhitungan gaji pegawai.

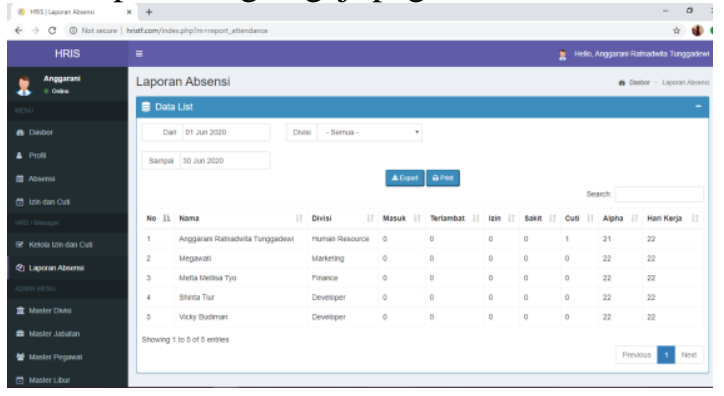

Gambar 9. Laporan Presensi Pegawai

\section{KESIMPULAN}

Berdasarkan hasil uji coba aplikasi dan uraian sebelumnya, maka diambil kesimpulan dari penulisan penelitian ini sebagai berikut :

1. Dengan aplikasi pengelolaan kepegawaian ini dapat membantu mengelola data absensi pegawai, pengajuan izin pegawai, dan pengajuan cuti pegawai.

2. Aplikasi pengelolaan kepegawaian ini berbasis web dan dapat diakses dengan local area network perusahaan, sehingga pegawai dapat mengakses dimana saja selama berada dalam jangkauan jaringan.

3. Dengan aplikasi pengelolaan kepegawaian ini dapat membantu HRD dalam pembuatan laporan absensi yang dibutuhkan dalam perhitungan gaji pegawai. 


\section{DAFTAR PUSTAKA}

Bassil, Youssef. 2012. A Simulation Model for the Waterfall Software Development Life Cycle. International Journal of Engineering \& Technology (iJET) 2012, Vol. 2, No. 5. ISSN: 2049-3444

Erinawati, Heni Dwi. 2012. Pembangunan Sistem Informasi Pembayaran Sekolah Pada Sekolah Menengah Atas (SMA) Negeri 1 Rembang Berbasis Web. Journal Speed-Sentra Penelitian Engineering dan Edukasi, Volume 4, No 4, 2012, hal.4046. ISSN: 1979-9330

Hussein, Faizal, Kertahadi, dan Riyadi. 2014. Implementasi Sistem Informasi Sumber Daya Manusia (Studi Kasus pada Perusahaan Jasa PT. Wiranas Laundry and Dry Cleaning Service). Jurnal Administrasi Bisnis (JAB), Vol. 10, No. 1, Mei 2014, Hal.1-11

Ismail, Hj. Iriani. Dr. 2010. Manajemen Sumber Daya Manusia, Malang : Lembaga Penerbitan Fakultas Pertanian Universitas Brawijaya Malang

Pramata, Riandy, Magnaz Lestari Oktaroza, dan Nunung Nurhayati. Perancangan Sistem Informasi Pengelolaan Lembaga Kursus Des-It Course. KAJIAN AKUNTANSI, PP 22-36. ISSN:1693-0164 